\title{
PENGARUH FILSAFAT REKONSTRUKSIONISME TERHADAP RUMUSAN KONSEP PENDIDIKAN SERTA TINJAUAN ISLAM TERHADAPNYA
}

\author{
Ali Mubin \\ alimubin1972@gmail.com \\ (Dosen Fakultas Agama Islam, Universitas Muhammadiyah Tangerang)
}

\begin{abstract}
Abstrak:
Rekontruksionisme mengasumsikan manusia makhluk sosial mempunyai orientasi ke masa lalu dan sekarang dengan tujuan pendidikan terhadap pembentukkan masyarakat yang lebih baik dengan kurikulum sebagai rekonstruksi sosial mengutamakan kepentingan sosial di atas kepentingan individu tujuannya tanggung jawab tentang masa depan masyarakat. Dan Pengaruh filsafat rekonstruksionisme terhadap pendidikan adanya perubahan rancangan kurikulum, metode, media, azas belajar, budaya dan sumber belajar ke arah yang lebih progresif yang dianggap mampu menjawab tantangan zaman, dan pendidikan harus memadukan antara daya nalar, pikir, akal dan rasio dengan hati yang menjadi patokan dan ukuran tingkah laku manusia dengan iman dan ketaqwaannya kepada Allah SWT.
\end{abstract}

\section{Kata Kunci: Filsafat, Rekonstruksionisme, Rumusan pendidikan Islam}

\section{A. Pendahuluan}

Kemunculan filsafat rekontruksionisme ini berangkat dari kondisi masyarakat Amerika pada khususnya dan masyarakat industri pada umumnya, yang semakin meninggalkan sebuah tatanan dunia yang diidamidamkan. Perkembangan ilmu, teknologi, dan industrialisasi pada satu sisi memberikan kontribusi positif bagi peningkatan kesejahteraan, akan tetapi disisi lain ia telah menimbulkan pengaruhpengaruh yang negatif. Masyarakat yang tenang, tentram, dan damai, pelan-pelan telah tergiring pada keterasingan. Ada yang menganggap, kondisi ini karena adanya sifat loises faire, kompetisi yang terlalu berlebihan sehingga bermuara pada pemenuhan kepentingan individual dari pada kepentingan sosial, pada masyarakat Amerika.

Perlu dilakukan perbaikan-perbaikan di bidang ekonomi, yang semula berbentuk individual interprenurship dirubah kearah coorperative yang bersendikan konsep kerja sama kolektif. Konsep ini, kemudian mampu meningkatkan taraf kehidupan masyarakat yang lebih baik. Keadaan ini, meyakinkan para pemikir pendidikan bahwa pendidikan perlu mempunyai konsep dan peran yang positif dalam mengadakan rekontruksi masyarakat. Masyarakat yang direkontruksi ini, hendaknya lebih mengutamakan kebersamaan dari pada kepentingankepentingan individu.

Pada dasarnya rekonstruksionisme sepaham dengan perealisme dalam hendak mengatasi krisis kehidupan modern. Hanya saja jalan yang ditempuh berbeda, jika perealisme memilih untuk kembali kepada kebudayaan lama yang telah teruji dan terbukti mampu membawa manusia mengatasi krisis sedangkan rekonstrukinisme berusaha membina suatu consensus yang paling luas dan paling 
mungkin mencapai tujuan utama dan tertinggi dalam kehidupan manusia untuk mencapai tujuan itu, rekonstruksinisme berusaha mencari kesepakatan semua orang mengenai tujuan utama yang dapat mengatur tata kehidupan manusia dalam suatu tatanan baru seluruh lingkungannya. Oleh karena itu, pada aliran rekonstruksionisme ini, peradaban manusia masa depan sangat ditekankan. Rekonstruksionisme menaruh perhatian terhadap pendidikan dalam kaitannya dengan masyarakat.

\section{B. Pemikiran Filsafat Rekonstruksionisme \\ 1. Pemikiran aliran filsafat rekonstruksionisme dalam bidang pendidikan}

Dalam filsafat pendidikan, aliran rekonstruksionisme merupakan suatu aliran yang berusaha merombak tata susunan lama dengan membangun tata susunan hidup kebudayaan yang bercorak modern. ${ }^{1}$ Aliran rekonstruksionisme pada prinsipnya sepaham dengan aliran perenialisme, yaitu berawal dari krisis kebudayaan modern. Menurut Muhammad Noor Syam, kedua aliran tersebut memandang bahwa keadaan sekarang merupakan zaman yang mempunyai kebudayaan yang terganggu oleh kehancuran, kebingungan dan kesimpangsiuran.

Meskipun demikan, prinsip yang dimiliki oleh aliran ini tidaklah sama dengan prinsip yang dipegang oleh aliran filsafat perenialisme. Keduanya mempunyai visi dan cara yang berbeda dalam pemecahan yang akan ditempuh untuk mengembalikan kebudayaan yang serasi dalam kehidupan. Aliran

${ }^{1}$ Ibid, hal. 118 perenialisme memilih cara tersendiri, yakni dengan kembali kea lam kebudayaan lama (regressive road culture) yang mereka anggap paling ideal. Sementara itu aliran rekonstruksionisme menempuhnya dengan jalan berupaya membina suatu consensus yang paling luas mengenai tujuan pokok dan tertinggi dalam kehidupan umat manusia. Aliran rekonstruksionisme berkeyakinan bahwa tugas penyelamatan dunia merupakan tugas semua umat manusia. Karenanya, pembinaan kembali daya intelektual spiritual yang sehat melalui pendidikan yang tepat dan membina kembali manusia dengan nilai dan norma yang benar pula demi generasi sekarang dan generasi yang akan datang, sehingga terbentuk dunia baru dalam pengawasan umat manusia. Di samping itu, aliran ini memiliki persepsi bahwa masa depan suatu bangsa merupakan suatu dunia yang diatur dan diperintah oleh rakyat secara demokratis, bukan dunia yang dikuasai oleh golongan tertentu. Cita-cita yang sesungguhnya tidak hanya teori, tetapi mesti diwujudkan menjadi kenyataan, sehingga mampu meningkatkan kualitas kesehatan, kesejahteraan dan kemakmuran serta keamanan masyarakat tanpa membedakan warna kulit, keturunan, nasionalisme, agama (kepercayaan) dan masyarakat bersangkutan.

\section{a. Pandangan Ontologis}

Aliran rekonstruksionisme memandang bahwa realita itu bersivat universal, realita itu ada dimana-mana dan sama disetiap tempat. Menurut Muhammad Noor Syam, untuk mengerti realita, kita tidak hanya harus melihat sesuatu yang konkrit tetapi juga sesuatu yang khusus, karena realita yang kita ketahui dan hadapi tidak terlepas dari suatu sistem, selain substansi yang dipunyai dari tiap sesuatu 
tersebut. Sebagai substansi, tiap realita itu selalu bergerak dan berkembang dari potensialitas menuju aktualitas, sehingga gerakan tersebut mencakup tujuan dan terarah, guna mencapai tujuannya masingmasing dengan caranya sendiri, karena tiap realita memiliki perspektif tersendiri.

Pada prinsipnya aliran rekonstruksionisme memandang alam metafisika merujuk dualism. Menurut Bakry, aliran ini berpendirian bahwa alam nyata ini mengandung dua macam hakikat sebagai asal sumber, yakni hakikat materi dan hakikat ruhani. Kedua macam hakikat ini memiliki ciri yang bebas dan berdiri sendiri, azali dan abadi.Dan hubungan keduanya menciptakan hubungan dalam alam. Menurut Descartes, pada umumnya manusia tidak sulit menerima prinsip dualism ini, yang menunjukkan bahwa kenyataan lahir dapat segera ditangkap oleh panca indera manusia, sementara kenyataan batin segera diakui dengan adanya akal dan perasaan hidup. Dibalik gerak realita sesungguhnya terdapat kausalitas yang menjadi pendorong dan penyebab utama atau kausa prima.Kausa prima ialah Tuhan, yang menggerakkan Kausa prima ialah Tuhan, yang menggerakkan sesuatu. Tuhan adalah aktualitas murni yang sama sekali sunyi dari substansi. Menurut Muhammad Noor Syam, pemikiran di atas berasal dari gerakan intelektualitas pada abad pertengahan yang mencapai kristalisasi pada abad IX - XIV, yang memberikan argumentasi rasio tentang eksistensi Tuhan. Seorang tokoh utama Scholastic, Alselpus, menyatakan bahwa secara kritis realita semesta dapat dipahami dan tidak ada sesuatu di alam nyata ini di luar kekuasaan Tuhan, karena semua itu sebagai perwujudan dari kesempurnaan-
Nya. Dalam perkembangan selanjutnya, penafsiran ini didukung oleh Thomas Aquinas. Menurut Thomas Aquinas, untuk mengetahui realita yang ada harus berdasarkan iman, sementara perkembangan rasional hanya dapat dijawab dan mesti diikuti dengan iman.

\section{b. Pandangan Epistimologis}

Kajian epistimologis, aliran ini lebih merujuk kepada pendapat aliran pragmatism dan perenialisme.Menurut aliran ini, untuk memahami realita memerlukan suatu asas tahu. Maksudnya, kita tidak mungkin memahami realita ini tanpa melalui proses pengalaman dan hubungan dengan realita terlebih dahulu melalui penemuan ilmu pengetahuan. Karenanya, baik indera maupun rasio sama-sama berfungsi membentuk pengetahuan yang sesungguhya.

Aliran ini juga berpendapat bahwa dasar dari suatu kebenaran dapat dibuktikan dengan self-efidence, yakni bukti yang ada pada diri sendiri, realita dan eksistensinya. Dengan kata lain pengetahuan yang benar buktinya ada di dalam pengetahuan ilmu itu sendiri. Sebagai ilustrasi, adanya Tuhan tidak perlu dibuktikan dengan bukti-bukti lain atas eksistensi Tuhan. Pedoman aliran ini berasal dari ajaran Aristoteles yang membicarakan dua hal pokok, yakni pikiran (ratio) dan bukti (efidence) yang menggunakan jalan silogisme. Silogisme menunjukkan hubungan logis antara premis mayor, premis minor, dan kesimpulan (conclusion), yang memakai cara pengambilan kesimpulan deduktif dan induktif.

\section{c. Pandangan Aksiologis}

Dalam proses interaksi sesama manusia diperlukan nilai-nilai. Begitu juga dalam hubungan manusia dengan alam 
semesta, prosesnya tidak mungkin dilakukan dengan sikap netral. Dalam hal ini, manusia sadar ataupun tidak sadar telah melakukan proses penilaian, yang merupakan kecenderungan manusia. Tapi secara umum ruang lingkup pengertian "nilai" ini tidak terbatas. Menurut Barnadib, aliran rekontruksionisme memandang masalah nilai berdasarkan asas-asas supranatural, yaitu menerima nilai natural yang universal, yang abadi, berdasarkan prinsip nilai teologis. Hakikat manusia adalah emanasi potensial yang berasal dari Tuhan. Atas dasar pandangan inilah tinjauan tentang kebenaran dan keburukan dapat diketahui. Kemudian manusia sebagai subjek telah memiliki potensi-potensi keabadian dan keburukan sesuai dengan kodratnya. Kebaikan itu akan tetap tinggi nilainya bila tidak dikuasai oleh hawa nafsu, disinilah akal berperan menentukan.

Neo-Thomisme memandang bahwa etika, estetika, dan politik sebagai cabang dari filsafat praktis yang berhubungan dengan prinsip-prinsip moral, kreasi estetika, dan organisasi politik. Karenanya, dalam arti teologis, manusia perlu mencapai kebaikan tertinggi, yakni bersatu dengan Tuhan, kemudian berfikir rasional. Terkait dengan masalah estetika, maka hakikat keindahan khusus atau pancaran dari unsur keindahan universal yang abadi yakni Tuhan.

\section{Pengaruh filsafat rekonstruksionisme terhadap asas belajar, kurikulum, budaya dan metode pendidikan.}

\section{a. Pengaruh filsafat rekontruksionisme} terhadap kurikulum

Kurikulum adalah sesuatu yang direncanakan sebagai pegangan guna mencapai tujuan pendidikan. Apa yang direncanakan biasanya bersifat idea, suatu cita-cita tentang manusia atau warga negara yang akan dibentuk. Kurikulum ini lazim mengandung harapan-harapan yang sering berbunyi muluk-muluk. ${ }^{2}$

Kurikulum dapat ditinjau dan ditafsirkan dari segi lain, diantaranya;

1) Kurikulum dapat dilihat sebagai produk, yakni sebagai hasil karya para pengembang kurikulum.

2) Kurikulum dipandang sebagai program, yakni alat yang dilakukan oleh sekolah untuk mencapai tujuannya, ini dapat berupa pembelajaran berbagai mata pelajaran tetapi dapat juga meliputi segala kegiatan yang dianggap dapat mempengaruhi perkembangan siswa.

3) Kurikkulum dapat pula dipandang sebagai hal-hal yang diharapkan akan dipelajari siswa, yakni pengetahuan, sikap keterampilan tertentu.

4) Kurikulum sebagai pengalaman siswa. Ketiga pandangan di atas berkenaan dengan perencanaan kurikulum, sedangkan pandangan ini mengenai apa yang secara aktual menjadi kenyataan pada tiap siswa. Ada kemungkinan, bahwa apa yang diwujudkan pada diri anak berbeda dengan apa yang diharapkan menurut rencana.

Para pengembang kurikulum harus mempunyai nilai filosofi yang jelas tentang apa yang mereka junjung tinggi. Filsafat yang kabur akan menimbulkan kurikulum yang tidak menentu arahnya. Kurikulum sebagai rekontruksi sosial mengutamakan kepentingan sosial di atas kepentingan individu. Tujuannya adalah tanggung jawab tentang masa depan masyarakat. Tugas kurikulum demikian bukanlah

${ }^{2}$ S. Nasution, Asas-asas Kurikulum, (Jakarta: Bumi Aksara, 1995), hal. 8 
sesuatu yang baru akan tetapi selalu merupakan suatu bagian dari fungsi pendidikan, karena pendidikan selalu berkaitan tujuannya dengan masa mendatang. Hingga manakah taraf tanggung jawab itu berbeda-beda menurut pendapat pendidik tertentu. Sekolah biasanya dipandang sebagai agen of social change, badan untuk mengadakan perubahan sosial. Sekolah merupakan jembatan antara masa kini dengan masa mendatang, antara realitas masa kini dengan masa datang. ${ }^{3}$

Dalam pendekatan ini terdapat dua aliran, yakni yang bersifat adaptif dan reformatories. Yang pertama menginginkan agar individu dipersiapkan untuk menghadapi perubahan-perubahan yang pasti terjadi di masa mendatang dengan harapan agar ia sanggup mempertahankan hidupnya dalam dunia yang serba dinamis dan tidak stabil ini. Untuk itu kurikulum perlu didasarkan atas masal-masalah sosial, ekonomi, politik sekarang agar murdi-murid mampu menghadapinya kelak. Golongan reformis bukan hanya mempersiapkan individu untuk menghadapi masalah di masa depan, akan tetapi juga menginginkan agar individu turut aktif mengadakan perubahan yang diinginkan. Salah seorang diantara mereka adalah Ivan Illic. Penganut kontruksi sosial mengutamakan hubungan kurikulum dengan masa depan masyarakat bukan dengan keadaan sekarang. Mereka menaruh kepercayaan atas kesanggupan manusia untuk membentuk masa depannya. ${ }^{4}$ Harold G. Shane, penganut reformis futurologist melihat kemungkinan bagi manusia untuk mengadakan pilihan

${ }^{3}$ S. Nasution, Pengembangan Kurikulum, (Bandung: Citra Aditia Bakti, 1993), hal. 24

${ }^{4}$ Ibid, hal. 25 tentang masyarakat yang akan dibentuk, bahkan suatu masyarakat yang ideal, utopia.

Tokoh lain yang terkenal adalah Paulo Freire, melaksanakan pendekatan ini di dunia ketiga. Ia berusaha agar orang menyadari benar-benar keadaan sosiokulturalnya di mana ia hidup agar mereka tergerak untuk mengubahnya dan memperbaiki nasibnya. Banyak kesulitan menurut Freire yang dihadapinya, antara lain cara berfikir masyarakat yang telah dipengaruhi dan dikendalikan oleh masmedia, sistem pendidikan yang mempertahankan status quo, dan pemimpin-pemimpin politik yang mendahulukan kepentingan golongan elite di atas kepentingan masyarakat banyak.

\section{b. Pengaruh filsafat rekontruksionisme terhadap asas belajar}

Menurut Jerome Bruner, belajar adalah memperoleh informasi, yang bersamaan atau yang bertentangan dengan yang ada, mentransformasinya, yaitu memanipulasinya dengan intrapolasi dan ekstrapolasi, agar sesuai dengan tugas yang dihadapi, dan mengecek keserasiannya dengan tugas. Untuk ini diperlukan pertimbangan dan penilaian. ${ }^{5}$

Ada dua prinsip penting yang dikemukakan dalam tulisan Bruner, yakni;

1) Perolehan pengetahuan adalah proses aktif

2) Individu secara aktif merekontruksi pengalamannya dengan menghubungkan pengetahuan baru dengan "internal modal" atau struktur kognitif yang telah dimilikinya.

Pendekatan Bruner disebutnya "konseptualisme instrumental" berdasarkan dua segi proses kognitif, yakni:

${ }^{5} \mathrm{~S}$. Nasution, Asas-asas Kurikulum, (Jakarta: Bumi Aksara, 1995), hal. 85 
1) Manusia mengkontruksi model pada dirinya tentang dunia realitas, dan ia mengenal dunia berdasarkan model itu.

2) Model itu semula diadopsi, diterima dari kebudayaannya, kemudian mengadopsi, menyesuaikannya bagi keperluan dirinya. Persepsi pada hakikatnya proses konstruktif, mengkatagorisasi informasi atau mengangkat informasi pada taraf katagori. Karena itu manusia tidak pasif, juga tidak reaktif, melainkan aktif.

Menurut Bruner, sekolah didirikan masyarakat sebagai alat untuk meningkatkan kemampuan intlektual anak, dengan cara:

1) Menerjemahkan teori menjadi struktur yang dapat dipahami anak melalui dialog antar guru dan anak

2) Mengembangkan rasa kepercayaan pada siswa akan kemampuannya memecahkan masalah dengan menggunakan kemampuan mentalnya.

3) Membimbing siswa agar ia sendiri dapat mempelajari berbagai macam bahan pelajaran atau memecahkan masalah yang dirumuskannya sendiri, menggunakan kemampuan mentalnya secara ekonomis dengan mencari relevansi dan memahami struktur bahan yang dipelajarinya serta memupuk kejujuran intelektual.

\section{Prinsip-prinsip Belajar}

Menurut S. Nasution, belajar itu tidak sesederhana seperti digambarkan oleh ilmu jiwa, melainkan sangat kompleks. Dari hasil penelitiannya, ada beberapa prinsip belajar diantaranya:

1) Agar seorang benar-benar belajar ia harus mempunyai suatu tujuan. Tujuan itu harus timbul dari atau berhubungan dengan kebutuhan hidupnya dan bukan karena dipaksakan oleh orang lain. Seseorang harus bersedia mengalami bermacam-macam kesukaran dan berusaha dengan tekun untuk mencapai tujuan yang berharga baginya.

2) Selain tujuan pokok yang hendak dicapai, diperolehnya pula hasil-hasil sambilan atau sampingan, belajar lebih berhasil dengan jalan berbuat atau melakukan. Belajar sebagai keseluruhan aktivitas, tidak dengan otaknya atau secara intelektual saja, tetapi juga secara sosial, emosional, etis dan estetika.

3) Dalam hal belajar seorang memerlukan bantuan dan bimbingan dari orang lain. Untuk belajar diperlukan insight apa yang dipelajari harus benar-benar dipahami. Belajar bukan menghafal fakta lepas secara verbalitas.

4) Di samping mengejar tujuan belajar yang sebenarnya, seorang sering mengejar tujuan-tujuan lain, misalnya: orang belajar main badminton, juga ingin menjadi juara. Belajar lebih berhasil, apabila usaha itu memberi sukses yang menyenangkan.

5) Ulangan dan latihan perlu, akan tetapi harus didahului oleh pemahaman. Belajar hanya mungkin kalau ada kemauan dan hasrat untuk belajar. ${ }^{6}$

\section{Transfer Belajar}

Salah satu tujuan utama dalam pendidikan ialah transfer of leraning. Dengan transfer dimkasud kesanggupan seseorang untuk menggunakan suatu kecakapan, pengertian, prinsip-prinsip dan lain-lain yang diperolehnya dalam suatu lapangan ke dalam situasi yang baru.

${ }^{6}$ S. Nasution, Didaktik Asas-asas Mengajar, (Jakarta: Bumi Aksara, 1995), hal. 48 


\section{Jenis-jenis Belajar}

Menurut S. Nasution, bahwa belajar itu berhubungan erat dengan hal yang harus dipelajari, belajar berenang tidak sama sifatnya dengan belajar memecahkan soal matematika. Adapun jenis-jenis belajar menurut $\mathrm{S}$. Nasution adalah sebagai berikut;

1) Belajar berdasarkan pengamatan (sensory type of learning)

2) Belajar berdasarkan gerak (motor type learning)

3) Belajar berdasarkan hafalan (memory type learning)

4) Belajar berdasarkan pemecahan masalah (problem type of learning)

5) Belajar berdasarkan emosi (emotional type learning)

Azas-azas belajar tersebut, jelas sangat dipengaruhi oleh filsafat rekontruksionisme, karena tujuan belajar adalah bukan hanya otaknya saja, tetapi secara keseluruhan, baik secara sosial dan emosional, juga untuk bisa menata hidup yang lebih baik di masa yang akan datang.

\section{c. Pengaruh filsafat rekontruksionisme terhadap metode pendidikan}

Menurut Abudin Nata, dari segi bahasa metode berasal dari dua perkataan yaitu meta dan hodos. Meta berarti: "melalui" dan hodos berarti: "jalan" atau "cara". Dengan demikian metode dapat berarti cara atau jalan yang harus dilalui untuk mencapai suatu tujuan. Selain itu, adapula yang mengatakan bahwa metode adalah suatu sarana untuk menemukan, menguji, dan menyusun data yang diperlukan bagi pengembangan ilmu atau tersistemasikanya pemikiran. ${ }^{7}$

Pendidikan bisa diartikan secara luas dan sempit, pendidikan dalam pengertian

\footnotetext{
${ }^{7}$ Abudin Nata, Filsafat Pendidikan Islam, (Jakarta: Gaya Media Pratama, tt), hal. 143
}

sempit adalah sekolah, yaitu pengajaran yang diselenggarakan di sekolah sebagai lembaga formal, sedangkan dalam pengertian luas adalah, segala pengalaman belajar yang berlangsungkan dalam segala lingkungan dan sepanjang hidup. Bahwa pendidikan adalah segala situasi hidup yang mempengaruhi perkembangan individu. ${ }^{8}$ Adapun fungsi metode secara umum adalah sebagai pemberi jalan atau cara yang sebaik mungkin bagi pelaksanaan operasional dari ilmu pendidikan tersebut. Sedangkan dalam konteks lain metode dapat merupakam sarana untuk menemukan, menguji dan menyusun data yang diperlukan bagi pengembangan disiplin suatu ilmu. ${ }^{9}$ Adapun macam-macam metode pendidikan menurut Omar Muhammad al-Tommy alSyaibani, untuk dijadikan pegangan bagi seorang guru ada lima puluh enam metode yang terbagi dalam sebelas kelompok, yaitu sebagai berikut; ${ }^{10}$

1) Metode mengajar yang dasarnya pada alat-alat dan bahan-bahan yang digunakan padanya, seperti metode kitab, metode perpustakaan, metode laboratorium dan metode proyek.

2) Metode-metode yang berdasar pada cara yang diikutinya dalam mengemukakan fakta, seperti metode peraturan, metore lukis-lukisan, metode contoh, metode lawatan ilmiah dan pelajaran, metode partisipasi untuk latihan.

\footnotetext{
${ }^{8}$ Redja Mudyahardjo, Pengantar Pendidikan; Sebuah Studi Awal Tentang Dasar-dasar Pendidikan Pada Umumnya dan Pendidikan di Indonesia, (Jakarta: Raja Grafindi Persada), hal. 3

${ }^{9}$ Opcit, hal. 146

${ }^{10}$ Omar Muhammad al-Tomy, alih bahasa Hasan Langgulung, Filsafat Pendidikan Islam, (Jakarta: Bulan Bintang, 1979), hal. 558
} 
3) Metode yang berdasar pada penyusunan mata pelajaran, seperti metode penyusunan masa, metode penyusunan psikologi, metode penyusunan logic, metode penyusunan mengikuti perkara, mata pelajaran, unit pelajaran, atau mengikuti masalah kehidupan.

4) Metode berdasarkan pada tujuan yang dituju oleh guru, seperti metode nasiahat, petunjuk dan bimbingan, metode latihan, metode menikmati dan apresiasi, metode pemikiran, kesimpulan dan analisa, metode penaksiran dan metode pengembangan pengalaman.

5) Metode yang berdiri atas tujuan murid, seperti metode penyelesaian atas masalah, metode proyek.

6) Metode yang berhubungan atas timbal balik antara murid dan guru seperti metode pengangkatan, metode pelajaran terarah, metode proyek yang dipilih dengan bebas.

7) Metode yang berhungan timbal balik antara murid-murid antara yang satu dengan yang lain, seperti kegiatan perseorangan, metode kegiatan panitia, dan metode kegiatan kerjasama.

8) Metode-metode berdasarkan pada derajat keturutsertaan murid- murid pada proses pendidikan, seperti metode persembahan bersama murid-murid, metode keturutsertaan tersusun dari murid-murid, metode memperdengarkan bersama dan metode kegiatan dari pihak murid-murid.

9) Metode yang berdasar pada derajat kebebasan berfikir, seperti metode autokrasi atau tangan besi, metode pengambilan kesimpulan dari awal, metode kesimpulan terpimpin dan metode percobaan.
10) Metode yang digunakan pada cara dalam penilaian dan ulangan, seperti metode lisan, metode laporan tertulis, dan metode ujian tertulis.

11) Metode yang berdasarkan panca indra luar, seperti metode penglihatan, metode pendengaran, dan metode gerakan. ${ }^{11}$

Adapun menurut Abudin Nata, bahwa metode pendidikan terbagi atas 7 (tujuh) macam, yaitu;

1) Metode teladan

2) Metode kisah-kisah

3) Metode nasihat

4) Metode pembiasaan

5) Metode hukum dan ganjaran

6) Metode ceramah

7) Metode diskusi. ${ }^{12}$

d. Tinjauan Islam Terhadap Filsafat Rekontruksionisme

Pada prinsipnya filsafat rekrontruksionisme berupaya mencari kesepakatan antara sesama manusia agar dapat mengatur tata kehidupan manusia dalam suatu tatanan dan seluruh lingkungannya, maka pendidikan perlu merombak tata susunan lama dan membangun tata susunan hidup kebudayaan yang baru, sehingga perlu kerjasama antar umat manusia. Para tokoh pendidikan Islam telah banyak membahas, tentang pondasi pendidikan dalam Islam terutama filsafat sebagai konsep dasar maju mundurnya suatu pendidikan. Telah menjadi mafhum bersama bahwa keadaan masyarakat Islam diberbagai tempat dan negeri mengalami berbagai masalah budaya, ekonomi, sosial dan politik, Hal ini disebabkan karena kaum muslimin tidak melaksanakan dengan sempurna

\footnotetext{
${ }^{11}$ Ibid, hal. 560

${ }^{12}$ Abudin Nata, Filsafat Pendidikan Islam,
} (Jakarta: Gaya Media Pratama, tt), hal. 143 
ajaran-ajaran dan hukum-hukum agama dalam segala urusan kehidupannya. Begitu juga sebab keterbelakangan pemikirannya, melupakan pendidikan, dan mengikuti orang lain dalam segala hal.

Menurut Hasan Langgulung, bahwa langkah pertama yang harus diambil untuk memperbaiki proses pendidikan dalam sistem pendidikan yang dilaksanakan di negeri-negeri Islam adalah berusaha membina filsafat pendidikan yang menyeluruh, realistik, fleksibel mengambil landasan-landasan dan prinsip-prinsipnya dari prinsip-prinsip dan ajaran Islam yang mulia dan aqidahnya berkaitan dengan alam, manusia, masyarakat dan kehidupan. Juga yang berhubungan dengan watak ilmu pengetahuan manusia, watak-watak nilai moral dan watak proses pendidikan dan fungsinya dalam kehidupan. ${ }^{13}$ Aliran filsafat pendidikan yang digunakan oleh masyarakat muslim harus menggabungkan keaslian dan kemajuan serta bersumber dari Islam yang kekal, juga kandungankandungan yang terdiri dari aqidah yang sesuai dengan fitrah dan diterima oleh akal yang sehat, juga harus dikaitkan dengan akhlak, juga mengenai yang kaitannya hubungan antara manusia dengan semua yang ada dalam alam jagat yang luas baik benda atau bukan dengan penciptannya yaitu Allah SWT.

Jadi pada prinsipnya selagi aliran filsafat rekontruksionisme baik landasan ontologis, epistomologis dan aksiologisnya tidak bertentangan dengan konsep-konsep Islam di atas, maka Islam akan menerimanya dengan terbuka, tetapi apabila nilai-nilai filsafat tersebut bertentangan dengan konsep-konsep Islam tentu akan sendirinya akan ditolak.

\footnotetext{
${ }^{13}$ Hasan Langgulung, Asas-asas Pendidikan Islam, (Jakarta: Pustaka Al-Husana, 1992), hal. 37
}

\section{Kesimpulan}

Dari uraian tersebut di atas dapat disimpulkan bahwa filsafat rekontruksionisme mengasumsikan bahwa manusia itu adalah makhluk sosial yang mempunyai orientasi ke masa lalu dan sekarang dengan tujuan pendidikan terhadap pembentukkan masyarakat yang lebih baik dengan kurikulum sebagai rekonstruksi sosial mengutamakan kepentingan sosial di atas kepentingan individu yang tujuannya adalah tanggung jawab tentang masa depan masyarakat. Pengaruh filsafat rekonstruksionisme terhadap pendidikan yaitu adanya perubahan rancangan kurikulum, metode, media, azas belajar, budaya dan sumber belajar ke arah yang lebih progresif yang dianggap mampu menjawab tantangan jaman. Islam memandang bahwa pendidikan dianggap berhasil jika sanggup menyatukan antara idealitas dengan rasionalitas pelaku pendidikan. Lebih dalam Islam membuat konsep bahwa pendidikan harus memadukan antara daya nalar, pikir, akal dan rasio dengan hati yang menjadi patokan dan ukuran tingkah laku manusia. Out put pendidikan dikatakan baik jika menghasilkan para cendekiawan yang mahir dalam berbagai disiplin ilmu, juga hatinya beriman dan bertaqwa kepada Allah SWT.

\section{DAFTAR PUSTAKA}

Langgulung, Hasan, Asas-asas Pendidikan Islam, Jakarta: Pustaka Al-Husana, 1992.

Muhammad al-Tomy, Omar, alih bahasa Hasan Langgulung, Filsafat Pendidikan Islam, Jakarta: Bulan Bintang, 1979. 
Pengaruh Filsafat Rekonstruksionisme Terhadap Rumusan Konsep Pendidikan Serta Tinjauan Islam Terhadapnya

Mudyahardjo, Redja, Pengantar Pendidikan; Sebuah Studi Awal Tentang Dasar-dasar Pendidikan Pada Umumnya dan Pendidikan di Indonesia, Jakarta: Raja Grafindi Persada.

Nata, Abudin, Filsafat Pendidikan Islam, Jakarta: Gaya Media Pratama, 2006.

Nasution, S, Asas-asas Kurikulum, Jakarta: Bumi Aksara, 1995.
Didaktik Asas-asas Mengajar, Jakarta: Bumi Aksara, 1995.

Pengembangan Kurikulum, Bandung: Citra Aditia Bakti, 1993

Jalaludin dan Idi, Abdullah, Filsafat Pendidikan, Jogjakarta: Ar-Ruzz Media, 2007.

S. Praja, Juhaya, Aliran-aliran Filsafat dan Etika, Jakarta: Prenada Media, 2005. 
Pengaruh Filsafat Rekonstruksionisme Terhadap Rumusan Konsep Pendidikan Serta Tinjauan Islam Terhadapnya 